\title{
Exploring TM Image Texture and its Relationships with Biomass Estimation in Rondônia, Brazilian Amazon.
}

\author{
Dengsheng LU'; Mateus BATISTELLA ${ }^{2}$
}

\begin{abstract}
Many texture measures have been developed and used for improving land-cover classification accuracy, but rarely has research examined the role of textures in improving the performance of aboveground biomass estimations. The relationship between texture and biomass is poorly understood. This paper used Landsat Thematic Mapper (TM) data to explore relationships between TM image textures and aboveground biomass in Rondônia, Brazilian Amazon. Eight grey level co-occurrence matrix (GLCM) based texture measures (i.e., mean, variance, homogeneity, contrast, dissimilarity, entropy, second moment, and correlation), associated with seven different window sizes $(5 \times 5,7 \times 7,9 \times 9,11 \times 11,15 \times 15,19 \times 19$, and 25x25), and five TM bands (TM 2,3,4,5, and 7) were analyzed. Pearson's correlation coefficient was used to analyze texture and biomass relationships. This research indicates that most textures are weakly correlated with successional vegetation biomass, but some textures are significantly correlated with mature forest biomass. In contrast, TM spectral signatures are significantly correlated with successional vegetation biomass, but weakly correlated with mature forest biomass. Our findings imply that textures may be critical in improving mature forest biomass estimation, but relatively less important for successional vegetation biomass estimation.
\end{abstract}

KEYWORDS

texture, aboveground biomass, TM image, correlation, Amazon

\section{Explorando texturas de imagens TM e suas relaçóes com estimativas de Biomassa em Rondônia.}

\begin{abstract}
RESUMO
Muitas medidas de textura têm sido desenvolvidas e utilizadas para melhorar a acurácia de classificações de cobertura das terras, mas raramente têm-se avaliado a importância dessas medidas em estimativas de biomassa. Este trabalho utilizou dados Landsat TM para explorar as relações entre texturas de imagens TM e biomassa em Rondônia, Amazônia. Foram analisadas oito medidas de textura baseadas em matrizes de co-ocorrência de tons de cinza (i.e., média, variância, bomogeneidade, contraste, dissimilaridade, entropia, segundo momento e correlação), associadas com sete diferentes tamanbos de janela (5x5, 7x7, 9x9, 11x11, 15x15, 19x19 e 25x25) e cinco bandas TM (TM 2, 3, 4, 5 e 7). Índices de correlação de Pearson foram utilizados para analisar as relações entre textura e biomassa. Esta pesquisa indica que a maioria das medidas de textura são pouco correlacionadas com biomassa de vegetação secundária, mas algumas medidas de textura têm correlação significativa com a biomassa de formações florestais maduras. Ao contrário, assinaturas espectrais de bandas TM são significativamente correlacionadas com a biomass a de vegetação secundária, mas fracamente correlacionadas com a biomassa deflorestas maduras. Os resultados indicam que medidas de textura são importantes em estimativas de biomassa de floresta madura, mas relativamente menos importantes para estimativas de biomassa de vegetação secundária.
\end{abstract}

PALAVRAS-CHAVE

textura, biomassa, imagens TM, correlação, Amazônia

${ }^{1}$ Center for the Study of Institutions, Population, and Environmental Change (CIPEC), Indiana University, Bloomington, Indiana 47408, USA, ph. 812-856-3102; fax 812855-2634; dlu@indiana.edu

${ }^{2}$ Brazilian Agricultural Research Corporation, Embrapa Satellite Monitoring,Av. Dr. Júlio Soares de Arruda, 803, Campinas, São Paulo 13088-300, BRAZIL, ph. 55-19-32566009; fax 55-19-3254-1100; mb@cnpm.embrapa.br 


\section{ACTA AMAZONICA}

EXPLORING TM IMAGE TEXTURE AND ITS RELATIONSHIPS WITH BIOMASS ESTIMATION IN RONDÔNIA, BRAZILIAN AMAZON.

\section{INTRODUCTION}

Aboveground biomass governs the potential carbon emission that could be released to the atmosphere due to deforestation. Accurate biomass estimation is necessary to understand impacts of land-use/land-cover (LULC) change on global warming and environmental degradation. In recent years, biomass estimation has attracted scientific interest because regional changes in biomass have been associated with climate and ecosystem changes. The Large Scale BiosphereAtmosphere Experiment in Amazônia (LBA) has driven its attention to these issues contributing to the development of techniques for sustainable use of the land in the Amazon environment. The results presented in this article belong to a research project led by Indiana University and Embrapa Satellite Monitoring with the support of LBA.

The advantages of remotely sensed data over traditional field inventory methods for biomass estimation have been indicated by a number of publications (Sader et al., 1989; Roy \& Ravan, 1996; Boyd et al., 1999; Nelson et al., 2000; Steininger, 2000; Lu et al., 2002a). However, previous research has shown the difficulty of biomass estimation based purely on remotesensing spectral signatures because of the influence of increased canopy shadowing within large stands, the heterogeneity of vegetation stand structures, and spectral data saturation (Spanner et al., 1990; Roy \& Ravan, 1996; Steininger, 2000). The complexity of forest stand structure and species composition in the moist tropical regions result in highly variable standing stocks of biomass and even more variable rate of biomass accumulation following a deforestation event. This presents a challenge for biomass estimation, a challenge that must be addressed.

Texture often refers to the pattern of intensity variations in an image. Many texture measures have been developed (Haralick $e t$ al., 1973; He \& Wang, 1990; Unser, 1995; Riou \& Seyler, 1997). In previous research, texture measures were mainly used for LULC classification (Franklin \& Peddle, 1989; Marceau et al., 1990; Augusteijn et al., 1995; Franklin et al., 2000; ndi Nyoungui et al., 2002; Podest \& Saatchi, 2002). Of the many texture measures, the grey-level cooccurrence matrix (GLCM) may be the most common texture used for improving LULC classification (Marceau et al., 1990; Franklin et al., 2000; ndi Nyoungui et al., 2002). However, rarely has research focused on extraction of biomass information using texture measures. The relationships between textures and aboveground biomass are especially poorly understood. For example, how are textures related to biomass estimation? Which texture measure can effectively extract biomass information? During image processing, what size of moving window is appropriate for a specific texture measure? This paper examines image texture and vegetation aboveground biomass relationships using Landsat Thematic Mapper (TM) data in Rondônia, Brazilian Amazon, as an effort to find suitable textures for biomass estimation.

\section{METHODS}

\section{Study area}

Rondônia has experienced intensive LULC change in the past three decades. The deforestation rates in this State range from 1.14 to $2.62 \%$ per year between 1991 and 2000, much higher than the overall deforestation rate in the Brazilian Amazon region, which ranges from 0.37 to $0.80 \%$ per year at the same period (INPE, 2002). Following the national strategy of regional occupation and development, colonization projects initiated by the Brazilian government in the 1970s played a major role in this process (Moran, 1981). Most colonization projects in the state were designed to settle landless migrants. The immigrants transformed the forested landscape into a mosaic of cultivated crops, pastures, and different stages of successional forests (Batistella et al., 2003). Over the Amazon

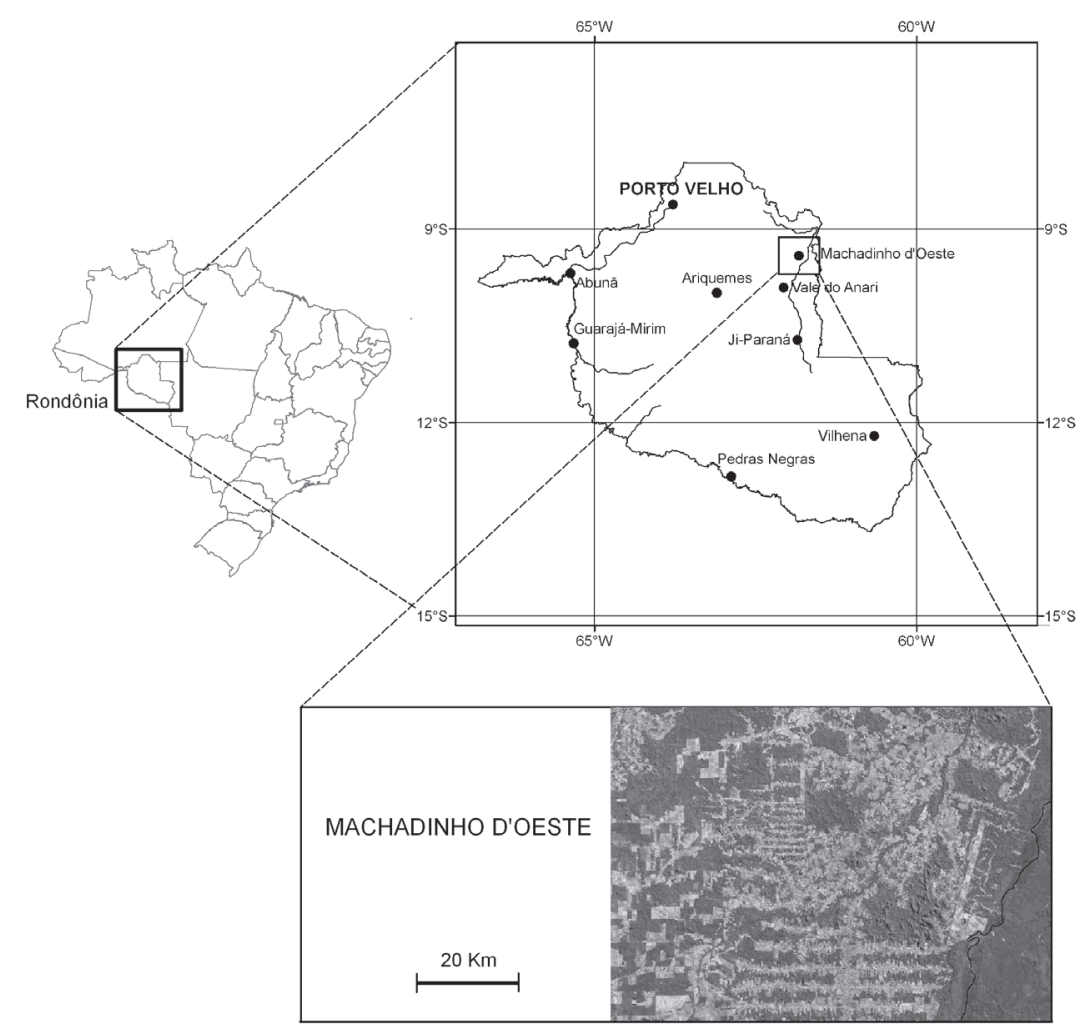

Figure 1 - Location of the study area in the State of Rondônia, Brazilian Amazon. 


\section{ACTA AMAZONICA}

region, a significant amount of the deforested area is in some stage of secondary succession, requiring that we carefully evaluate biomass and carbon dynamics represented by their heterogeneous vegetation stands.

To evaluate the relationship between image textures and aboveground biomass estimation, we chose the settlement of Machadinho d'Oeste, located in northeastern Rondônia (Figure 1). This is a newer colonization project than areas along BR-364 (Cuiabá-Porto Velho Highway). The settlement of Machadinho covers about $2,000 \mathrm{~km}^{2}$. Machadinho is adjacent to the borders with the States of Amazonas and Mato Grosso, which may offer potentials and constraints for future initiatives of conservation and development. The terrain is undulated, ranging from 100 to $450 \mathrm{~m}$ above sea level. The climate is classified as equatorial hot and humid, with tropical transition. The well-defined dry season lasts from June to August the annual average precipitation is 2,016 $\mathrm{mm}$, and the annual average temperature is $25.5^{\circ} \mathrm{C}$ (Rondônia, 1998). Several soil types, including alfisols, oxisols, ultisols, and alluvial soils have been identified (Bognola \& Soares, 1999).

\section{Field vegetation inventory and biomass estimation}

Fieldwork was conducted during the dry season of 1999. Preliminary image classification and band composite printouts indicated candidate areas to be surveyed, and a flight over the areas provided visual insights about the size, condition, and accessibility of each site. The surveys were conducted in areas with relatively homogeneous ecological conditions (e.g., topography, distance from water, and land use) and uniform physiognomic characteristics. After defining the area to be surveyed (plot sample), three subplots $\left(1 \mathrm{~m}^{2}, 9 \mathrm{~m}^{2}\right.$, and 100 $\mathrm{m}^{2}$ ) were randomly selected to accurately represent the variability within the plot sample. The center of each subplot was randomly selected. Total tree height, stem height (the height of the first main branch), and diameter at breast height
(DBH) were measured for all trees in the $100 \mathrm{~m}^{2}$ area. Height and $\mathrm{DBH}$ were measured for all saplings in the $9 \mathrm{~m}^{2}$ area. Ground cover estimation and counting of individuals were conducted for seedlings and herbaceous vegetation in the 1 $\mathrm{m}^{2}$ area. Here, seedlings were defined as young trees or shrubs with a stem diameter smaller than $2 \mathrm{~cm}$, saplings as young trees with a stem DBH greater than $2 \mathrm{~cm}$ and smaller than 10 $\mathrm{cm}$, and trees as woody plants with a DBH greater than or equal to $10 \mathrm{~cm}$. A detailed description of field data collection can be found in Batistella (2001) and Lu et al. (2004).

A total of 43 sample plots were inventoried, including 29 plots for different stages of successional vegetation and 14 plots for mature forests. Table 1 summarizes sample plot distributions as well as the statistical characteristics of aboveground biomass. The vegetation ages of successional forests range from 2 to 13 years.

A database was built to integrate all vegetation data collected during fieldwork. Equation (1) was used to calculate individual tree biomass (Brown et al., 1995) and Equation (2) for individual sapling biomass (Honzák et al., 1996).

$$
\begin{aligned}
& \mathrm{YT}=0.0326 "{ }^{\prime}(\mathrm{DT})^{2}{ }^{\prime \prime} \mathrm{H} \text { and } \quad(1) \\
& \mathrm{YS}=\exp \left[-3.068+0.957 \ln \left(\mathrm{DS}^{2}{ }^{\prime \prime} \mathrm{H}\right)\right],
\end{aligned}
$$

where DT and DS are the tree and sapling DBH in centimeters, respectively; $\mathrm{H}$ is the total tree or sapling height in meters; and YT and YS are the individual tree and sapling biomass in kilograms, respectively. Aboveground biomass (AGB: $\mathrm{kg} / \mathrm{m}^{2}$ ) was then calculated through Equation (3).

$\mathrm{AGB}=\sum_{i=1}^{m} Y T_{i} / \mathrm{PA}+\sum_{j=1}^{n} Y S_{j} / \mathrm{SPA}$,

where $m$ is the total tree number in a selected plot (three $100 \mathrm{~m}^{2}$ subplots in a plot), and $n$ is the total sapling number in a selected plot (three $9 \mathrm{~m}^{2}$ subplots in a plot). PA and SPA are the plot areas (in square meters) for tree and sapling measurements.

\begin{tabular}{|c|c|c|c|c|}
\hline \multirow[b]{2}{*}{ Sample plot distributions } & \multicolumn{2}{|c|}{ Successional forests } & \multicolumn{2}{|c|}{ Mature forests } \\
\hline & Biomass $\left(\mathrm{kg} / \mathrm{m}^{2}\right)$ & Plots $(\mathrm{N})$ & Biomass $\left(\mathrm{kg} / \mathrm{m}^{2}\right)$ & Plots(N) \\
\hline & $2-4$ & 5 & $10-14$ & 4 \\
\hline & $4-6$ & 5 & $14-18$ & 1 \\
\hline & $6-8$ & 4 & $18-22$ & 2 \\
\hline & $8-10$ & 5 & $22-26$ & 1 \\
\hline & $10-12$ & 1 & $26-30$ & 2 \\
\hline & $12-14$ & 4 & $30-34$ & 1 \\
\hline & $14-16$ & 4 & $34-38$ & 1 \\
\hline & $16-18$ & 1 & $>38$ & 2 \\
\hline Total plots & & 29 & & 14 \\
\hline \multirow{4}{*}{ Statistical characteristics } & Mean & 8.350 & \multicolumn{2}{|c|}{24.765} \\
\hline & Minimum & 2.397 & \multicolumn{2}{|c|}{11.132} \\
\hline & Maximum & 16.778 & \multicolumn{2}{|c|}{49.470} \\
\hline & Std. Dev. & 4.455 & \multicolumn{2}{|c|}{11.805} \\
\hline
\end{tabular}

Table 1 - Distribution of sample plots and statistical characteristics. 


\section{ACTA \\ AMAZONICA}

EXPLORING TM IMAGE TEXTURE AND ITS RELATIONSHIPS WITH BIOMASS ESTIMATION IN RONDÔNIA, BRAZILIAN AMAZON.

\section{Image preprocessing and extraction of TM textures}

Accurate geometric rectification and atmospheric calibration are two important aspects in image preprocessing. In this research, Landsat 5 TM data acquired on June 18, 1998 were geometrically rectified using control points taken from topographic maps at 1:100,000 scale. Nearest-neighbor resampling technique was used to resample the original TM image into a pixel size of $30 \mathrm{~m}$ by $30 \mathrm{~m}$. A root-mean-square error with less than 0.5 pixels was obtained in rectification. An improved image-based dark object subtraction model was used to calibrate the atmospheric impacts on the TM image spectral responses (Lu et al., 2002b). The gain and offset for each band, and the sun elevation angle were obtained from the image header file. Taking clear water as a reference, the path radiance was identified for each band. The atmospheric transmittance values for visible and near infrared bands were an average for each spectral band derived from radiative transfer code (Chavez, 1996). For middle infrared bands, the atmospheric transmittance was set to one. The surface reflectance values after calibration fall within the range between 0 and 1 . For the convenience of data analysis, the reflectance values were rescaled to the range between 0 and 100 by multiplying 100 for each pixel value. After image preprocessing, eight GLCM based texture measures (Table 2), associated with five TM bands (bands TM 2, 3, 4, 5, and 7), and seven different sizes of moving windows $(5 \times 5,7 \times 7,9 \times 9,11 \times 11,15 \times 15,19 \times 19$, and $25 \times 25$ ) were calculated.

\section{RESULTS}

\section{Relationships between GLCM textures and successional vegetation biomass}

Table 3 summarizes the relation-ships between successional vegetation biomass and GLCM textures associated with different window sizes and TM bands. The majority of textures are wea-kly correlated with successional vegetation biomass. Only a few textures (i.e., mean and variance textures) are significantly correlated with biomass. For example, texture mean with band TM 4 and window sizes of $5 \times 5,7 \times 7,9 \times 9$, and $11 \times 11$; texture mean with band TM 5 and $5 \times 5,7 \times 7$, and $9 \times 9$; and texture variance with TM 4 and window sizes of $15 \times 15$ and 19x19 are significantly correlated with successional vegetation biomass. Their coefficients range from 0.42 to 0.54 . In contrast, the TM spectral signatures of all bands are significantly correlated with successional vegetation biomass. The coefficients range from 0.42 to 0.68 . Band TM 4 has the highest correlation value. These findings imply that spectral signatures are more effective than textures in successional vegetation biomass estimation. However, selecting a suitable texture, such as texture variance associated with band TM 4 and a window size of $15 \times 15$ may be useful for improving the successional vegetation biomass estimation.

\section{Analysis of texture and aboveground biomass relationships}

To link biomass content of sample plots with TM textures, a set of procedures was undertaken. A window size of 3 by 3 pixels was used to extract the mean texture value for each plot of successional vegetation and mature forests. Pearson's correlation coefficient was used to analyze the relationships between texture and successional vegetation or mature forest biomass. The correlation coefficient measures the strength of linear relationships between two variables. A higher correlation coefficient implies a stronger linear relationship between these two variables. In this study, biomass and texture values were the main variables analyzed. As a comparison, the relationship between TM spectral signatures and biomass was also analyzed.
Table 2 - Texture measures used for the study area in Rondônia, Brazilian Amazon.

\begin{tabular}{|c|c|c|}
\hline No. & Texture measures & Formula \\
\hline 1 & Mean (ME) & $\mathrm{ME}=\sum_{i, j=0}^{N-1} i\left(P_{i},{ }_{j}\right)$ \\
\hline 2 & Variance (VA) & $\mathrm{VA}=\sum_{i, j=0}^{N-1} i P_{i}, j(i-M E)^{2}$ \\
\hline 3 & Homogeneity $(\mathrm{HO})$ & $\mathrm{HO}=\sum_{i, j=0}^{N-1} i \frac{P_{i}, j}{1+(i-j)^{2}}$ \\
\hline 4 & Contrast (CO) & $\mathrm{CO}=\sum_{i, j=0}^{N-1} P_{i}, j(i-j)^{2}$ \\
\hline 5 & Dissimilarity (DI) & $\mathrm{DI}=\sum_{i, j=0}^{N-1} P_{i},_{j}|i-j|$ \\
\hline 6 & Entropy (EN) & $\mathrm{EN}=\sum_{i, j=0}^{N-1} i P_{i},_{j}\left(-\ln P_{i, j}\right)$ \\
\hline 7 & Second Moment (SM) & $\mathrm{SM}=\sum_{i, j=0}^{N-1} P_{i},_{j}^{2}$ \\
\hline 8 & Correlation (CC) & $C C=\sum_{i, j=0}^{N-1} i P_{i},_{j}\left[\frac{(i-M E)(j-M E)}{\sqrt{\mathrm{VA}_{i} \mathrm{AA}_{j}}}\right.$ \\
\hline
\end{tabular}


Table 3 - Pearson's correlation coefficients between GLCM based textures and successional vegetation biomass for the study area in Rondônia, Brazilian Amazon.

\begin{tabular}{|c|c|c|c|c|c|c|c|c|c|}
\hline \multirow{2}{*}{ TM } & \multirow{2}{*}{$\mathrm{TX}$} & \multicolumn{7}{|c|}{ Window sizes } & \multirow{2}{*}{$\begin{array}{l}\text { Spectral } \\
\text { signature }\end{array}$} \\
\hline & & $5 \times 5$ & $7 \times 7$ & $9 \times 9$ & $11 \times 11$ & $15 \times 15$ & $19 \times 19$ & $25 \times 25$ & \\
\hline \multirow{8}{*}{ TM 2} & ME & $-0.472^{*}$ & -0.368 & -0.250 & -0.181 & -0.11 & -0.079 & -0.055 & \multirow{8}{*}{$-0.508^{*}$} \\
\hline & VA & 0.119 & 0.211 & 0.188 & 0.100 & -0.016 & -0.060 & -0.095 & \\
\hline & $\mathrm{HO}$ & 0.018 & -0.034 & -0.061 & -0.056 & -0.049 & -0.024 & -0.092 & \\
\hline & $\mathrm{CO}$ & 0.297 & 0.256 & 0.174 & 0.091 & 0.057 & 0.051 & 0.070 & \\
\hline & DI & 0.132 & 0.148 & 0.121 & 0.081 & 0.060 & 0.043 & 0.088 & \\
\hline & EN & -0.019 & 0.051 & 0.048 & 0.016 & -0.037 & -0.077 & -0.050 & \\
\hline & SM & 0.041 & -0.008 & -0.003 & 0.032 & 0.098 & 0.153 & 0.113 & \\
\hline & $\mathrm{CC}$ & 0.093 & -0.127 & -0.173 & -0.187 & -0.132 & -0.007 & 0.038 & \\
\hline \multirow{8}{*}{ TM 3} & ME & -0.309 & -0.231 & -0.153 & -0.123 & -0.098 & -0.089 & -0.076 & \multirow{8}{*}{$-0.441^{*}$} \\
\hline & VA & 0.215 & 0.225 & 0.155 & 0.037 & -0.060 & -0.095 & -0.119 & \\
\hline & $\mathrm{HO}$ & -0.220 & -0.229 & -0.209 & -0.179 & -0.134 & -0.074 & -0.128 & \\
\hline & $\mathrm{CO}$ & 0.284 & 0.202 & 0.070 & -0.018 & -0.044 & -0.035 & 0.006 & \\
\hline & $\mathrm{DI}$ & 0.262 & 0.231 & 0.156 & 0.096 & 0.057 & 0.025 & 0.060 & \\
\hline & EN & 0.264 & 0.233 & 0.184 & 0.128 & 0.051 & -0.005 & 0.003 & \\
\hline & SM & -0.260 & -0.279 & -0.223 & -0.143 & -0.025 & 0.061 & 0.043 & \\
\hline & $\mathrm{CC}$ & -0.082 & 0.025 & -0.050 & -0.235 & -0.279 & -0.205 & -0.165 & \\
\hline \multirow{8}{*}{ TM 4} & ME & $-0.501^{*}$ & $-0.475^{*}$ & $-0.453^{*}$ & $-0.423^{*}$ & -0.331 & -0.222 & -0.123 & \multirow{8}{*}{$-0.680^{*}$} \\
\hline & VA & 0.056 & 0.012 & -0.106 & -0.287 & $-0.482^{*}$ & $-0.475^{*}$ & -0.361 & \\
\hline & $\mathrm{HO}$ & 0.082 & 0.031 & -0.010 & -0.019 & -0.033 & 0.001 & -0.014 & \\
\hline & $\mathrm{CO}$ & -0.090 & -0.093 & -0.073 & -0.099 & -0.175 & -0.244 & -0.192 & \\
\hline & $\mathrm{DI}$ & -0.061 & -0.048 & -0.031 & -0.051 & -0.098 & -0.158 & -0.137 & \\
\hline & EN & 0.177 & 0.101 & 0.039 & -0.059 & -0.110 & -0.047 & -0.116 & \\
\hline & $\mathrm{SM}$ & -0.200 & -0.101 & -0.033 & -0.077 & 0.151 & -0.300 & 0.034 & \\
\hline & $\mathrm{CC}$ & -0.008 & 0.063 & -0.048 & -0.128 & -0.236 & -0.165 & 0.150 & \\
\hline \multirow{8}{*}{ TM 5} & ME & $-0.539^{*}$ & $-0.495^{*}$ & $-0.423^{*}$ & -0.363 & -0.287 & -0.244 & -0.170 & \multirow{8}{*}{$-0.571^{*}$} \\
\hline & VA & 0.262 & 0.294 & 0.277 & 0.212 & 0.073 & -0.050 & -0.146 & \\
\hline & $\mathrm{HO}$ & -0.218 & -0.279 & -0.283 & -0.274 & -0.215 & -0.158 & -0.179 & \\
\hline & $\mathrm{CO}$ & 0.289 & 0.257 & 0.176 & 0.128 & 0.059 & -0.042 & -0.043 & \\
\hline & DI & 0.269 & 0.276 & 0.228 & 0.193 & 0.126 & 0.039 & 0.044 & \\
\hline & EN & 0.244 & 0.202 & 0.173 & 0.178 & 0.134 & 0.036 & -0.035 & \\
\hline & SM & -0.238 & -0.175 & -0.135 & -0.195 & -0.101 & -0.043 & -0.111 & \\
\hline & $\mathrm{CC}$ & 0.213 & 0.224 & 0.187 & 0.015 & -0.103 & -0.100 & -0.142 & \\
\hline \multirow{8}{*}{ TM 7} & ME & -0.351 & -0.306 & -0.234 & -0.195 & -0.172 & -0.173 & -0.128 & \multirow{8}{*}{$-0.424^{*}$} \\
\hline & VA & 0.168 & 0.237 & 0.213 & 0.135 & 0.004 & -0.095 & -0.130 & \\
\hline & $\mathrm{HO}$ & 0.072 & -0.006 & -0.004 & 0.003 & 0.001 & -0.002 & -0.037 & \\
\hline & $\mathrm{CO}$ & 0.203 & 0.168 & 0.073 & 0.023 & 0.001 & -0.026 & 0.029 & \\
\hline & $\mathrm{DI}$ & 0.077 & 0.098 & 0.045 & 0.014 & 0.001 & -0.010 & 0.039 & \\
\hline & EN & -0.031 & 0.103 & 0.140 & 0.113 & 0.033 & -0.033 & -0.065 & \\
\hline & SM & 0.055 & -0.063 & -0.122 & -0.099 & -0.051 & 0.009 & 0.068 & \\
\hline & $\mathrm{CC}$ & 0.181 & 0.073 & 0.020 & -0.040 & -0.007 & 0.018 & 0.042 & \\
\hline
\end{tabular}

NOTE: $\quad$ ‘* means significant at 0.05 confidence level. 
Table 4 - Pearson's correlation coefficients between GLCM based textures and mature forest biomass for the study area in Rondônia, Brazilian Amazon.

\begin{tabular}{|c|c|c|c|c|c|c|c|c|c|}
\hline \multirow{2}{*}{ TM } & \multirow{2}{*}{$\mathrm{TX}$} & \multicolumn{7}{|c|}{ Window sizes } & \multirow{2}{*}{$\begin{array}{l}\text { Spectral } \\
\text { signature }\end{array}$} \\
\hline & & $5 \times 5$ & $7 \times 7$ & $9 \times 9$ & $11 \times 11$ & $15 \times 15$ & $19 \times 19$ & $25 \times 25$ & \\
\hline \multirow{8}{*}{ TM 2} & ME & -0.137 & -0.096 & -0.049 & 0.007 & 0.148 & 0.266 & 0.354 & \multirow{8}{*}{0.015} \\
\hline & VA & -0.220 & 0.006 & 0.031 & 0.021 & 0.164 & 0.422 & $0.575^{*}$ & \\
\hline & $\mathrm{HO}$ & 0.172 & 0.055 & -0.181 & -0.319 & -0.389 & -0.439 & -0.440 & \\
\hline & $\mathrm{CO}$ & -0.043 & 0.142 & 0.203 & 0.260 & 0.324 & 0.445 & $0.535^{*}$ & \\
\hline & $\mathrm{DI}$ & -0.148 & 0.004 & 0.227 & 0.348 & 0.403 & 0.478 & 0.498 & \\
\hline & EN & -0.221 & -0.161 & -0.034 & 0.078 & 0.163 & 0.243 & 0.307 & \\
\hline & SM & 0.204 & 0.147 & 0.076 & -0.012 & -0.085 & -0.178 & -0.218 & \\
\hline & $\mathrm{CC}$ & 0.330 & 0.190 & -0.019 & -0.093 & -0.030 & 0.009 & -0.065 & \\
\hline \multirow{8}{*}{ TM 3} & ME & -0.108 & -0.108 & -0.085 & -0.024 & 0.158 & 0.307 & 0.398 & \multirow{8}{*}{0.04} \\
\hline & VA & -0.025 & 0.070 & 0.049 & 0.030 & 0.180 & 0.445 & $0.594^{*}$ & \\
\hline & $\mathrm{HO}$ & 0.099 & -0.030 & -0.190 & -0.317 & -0.455 & -0.489 & -0.485 & \\
\hline & $\mathrm{CO}$ & 0.117 & 0.423 & 0.208 & 0.266 & 0.344 & 0.465 & $0.543^{*}$ & \\
\hline & $\mathrm{DI}$ & -0.055 & 0.131 & 0.309 & 0.394 & 0.470 & $0.552^{*}$ & $0.549^{*}$ & \\
\hline & EN & -0.031 & -0.055 & -0.017 & 0.010 & 0.133 & 0.238 & 0.336 & \\
\hline & SM & 0.083 & 0.157 & 0.188 & 0.182 & 0.083 & 0.002 & -0.116 & \\
\hline & $\mathrm{CC}$ & 0.065 & 0.115 & 0.070 & 0.046 & -0.037 & -0.023 & -0.127 & \\
\hline \multirow{8}{*}{ TM 4} & ME & -0.241 & -0.285 & -0.275 & -0.216 & -0.118 & -0.075 & -0.036 & \multirow{8}{*}{0.032} \\
\hline & VA & 0.096 & 0.084 & 0.055 & 0.054 & 0.109 & 0.132 & 0.166 & \\
\hline & $\mathrm{HO}$ & -0.229 & -0.224 & -0.227 & -0.272 & -0.343 & -0.410 & -0.372 & \\
\hline & $\mathrm{CO}$ & 0.212 & 0.280 & 0.320 & 0.367 & 0.458 & 0.406 & 0.327 & \\
\hline & DI & 0.167 & 0.231 & 0.282 & 0.346 & 0.448 & 0.445 & 0.379 & \\
\hline & EN & 0.015 & 0.039 & -0.032 & -0.046 & -0.058 & 0.014 & 0.128 & \\
\hline & $S M$ & -0.046 & 0.016 & 0.062 & 0.041 & 0.015 & -0.080 & -0.430 & \\
\hline & $\mathrm{CC}$ & 0.059 & -0.159 & 0.052 & 0.019 & 0.183 & 0.183 & 0.070 & \\
\hline \multirow{8}{*}{ TM 5} & ME & $-0.574^{*}$ & $-0.621^{*}$ & $-0.609^{*}$ & -0.491 & -0.181 & 0.027 & 0.192 & \multirow{8}{*}{-0.397} \\
\hline & VA & 0.054 & 0.080 & 0.072 & 0.111 & 0.386 & $0.565^{*}$ & $0.587^{*}$ & \\
\hline & $\mathrm{HO}$ & 0.004 & -0.113 & -0.207 & -0.279 & -0.436 & -0.529 & $-0.549^{*}$ & \\
\hline & $\mathrm{CO}$ & 0.158 & 0.290 & 0.373 & 0.485 & $0.602^{*}$ & $0.626^{*}$ & $0.588^{*}$ & \\
\hline & $\mathrm{DI}$ & 0.059 & 0.210 & 0.338 & 0.439 & $0.567^{*}$ & $0.600^{*}$ & $0.577^{*}$ & \\
\hline & EN & 0.108 & 0.077 & -0.015 & 0.001 & 0.018 & 0.100 & 0.219 & \\
\hline & $S M$ & -0.095 & -0.030 & 0.104 & -0.055 & 0.019 & -0.040 & -0.20 & \\
\hline & $\mathrm{CC}$ & -0.512 & -0.078 & 0.145 & 0.261 & $0.576^{*}$ & 0.490 & 0.174 & \\
\hline \multirow{8}{*}{ TM 7} & ME & -0.498 & $-0.554^{*}$ & -0.526 & -0.377 & -0.062 & 0.140 & 0.289 & \multirow{8}{*}{-0.287} \\
\hline & VA & -0.048 & -0.018 & 0.028 & 0.076 & 0.327 & $0.545^{*}$ & $0.568^{*}$ & \\
\hline & $\mathrm{HO}$ & 0.112 & 0.017 & -0.143 & -0.310 & -0.477 & -0.511 & -0.502 & \\
\hline & $\mathrm{CO}$ & -0.206 & 0.089 & 0.217 & 0.348 & 0.471 & $0.554^{*}$ & $0.556^{*}$ & \\
\hline & $\mathrm{DI}$ & -0.150 & 0.008 & 0.192 & 0.350 & 0.489 & $0.544^{*}$ & 0.532 & \\
\hline & EN & 0.234 & 0.080 & 0.124 & 0.167 & 0.237 & 0.279 & 0.340 & \\
\hline & $S M$ & -0.317 & -0.226 & -0.213 & -0.204 & -0.217 & -0.246 & -0.275 & \\
\hline & CC & -0.044 & -0.031 & -0.150 & -0.139 & -0.089 & 0.078 & -0.037 & \\
\hline
\end{tabular}

NOTE: $\quad *$ means significant at 0.05 confidence level.

TX means texture measures 


\section{ACTA AMAZONICA}

\section{Relationships between GLCM textures and mature forest biomass}

Table 4 provides the relationships between mature forest biomass and GLCM textures associated with different window sizes and TM bands. Although most textures are weakly correlated with mature forest biomass, some specific textures are significantly correlated with it. For example, texture variance, contrast, and dissimilarity associated with bands TM 5 or TM 7 and window sizes of $19 \times 19$ or $25 \times 25$ are significantly correlated with mature forest biomass. Conversely, no TM spectral signatures are significantly correlated with mature forest biomass. This indicates that textures maybe critical variables for mature forest biomass estimation. Spectral signatures per se are not sufficient to accurately estimate mature forest biomass. The use of textures or incorporation of textures and spectral signatures is especially necessary to improve the performance of mature forest biomass estimation.

\section{DISCUSSION}

This study shows that most textures derived from Landsat TM data are weakly correlated with successional vegetation biomass, but some specific textures are significantly correlated with mature forest biomass. In contrast, TM spectral signatures are significantly correlated with successional vegetation biomass, but weakly correlated with mature forest biomass. The main reason for these findings is the variation in stand structures because optical sensors mainly capture canopy information and associated canopy shadows. In the study area, most successional vegetation stands were less than 10 years old, belonging to initial and intermediate secondary succession. In these stages, the density of saplings and young trees is high, and they account for most of the aboveground biomass (Batistella, 2001; Lu et al., 2003). There is no clear stratification between canopy and understory layers. Hence, the impacts of canopy shadows on TM reflectance are limited in the successional stages. Textures smooth the differences of the spectral features among different successional vegetation stages, resulting in poor relationships between textures and successional vegetation biomass.

In mature forest, aboveground biomass and vegetation density can vary considerably depending on soil conditions, species composition, and topography at the sites. Large trees occupy the canopy. Trees with DBH larger than $25 \mathrm{~cm}$ dominate, and a considerable number of individuals have a DBH of greater than $30 \mathrm{~cm}$. Many tree individuals are taller than $15 \mathrm{~m}$, and some between 20 and $30 \mathrm{~m}$ are present, followed by a few scattered emergent individuals with total height of greater than $30 \mathrm{~m}$. The shade content increases because the canopy layer becomes more heterogeneous, reducing the TM reflectance and resulting in reflectance saturation (Lu et al., 2003). Thus, TM spectral signatures cannot effectively reflect the biomass differences between distinct mature forest sites although their biomass amounts vary significantly. The textures can reduce the shade impacts and more effectively extract the biomass information for mature forest, hence, increasing the correlations between texture and mature forest biomass.
Selection of suitable textures for biomass estimation is still a challenge task because textures vary with the characteristics of the landscape under investigation and images used. Identifying suitable textures often involves the determination of appropriate texture measures, moving window sizes, image bands, and so on (Franklin et al., 1996; Chen et al., 2004). Not all texture measures can effectively extract biomass information. Even for the same texture measure, selecting an appropriate window size and image band is crucial. A small window size such as $3 \times 3$ often exaggerates the difference within the moving windows, increasing the noise content on the texture image. On the other hand, too large window sizes such as $31 \times 31$ or larger cannot effectively extract texture information due to smoothing the texture variation. Also, a large window size implies more processing time. In practice, it is still difficult to identify which texture measures, window sizes, and image bands are best suitable for a specific research topic and lack of a guideline on how to select an appropriate texture. For the study area in Rondônia, Brazilian Amazon, texture variance, contrast, and dissimilarity associated with band TM 5 and a 19x19 window size provided the best correlation with mature forest biomass. This implies that an optimal window size associated with an optimal TM band exists for extraction of biomass information in a specific forest stand structure. Caution needs to be taken when textures are used for extracting specific information such as biomass in different sites because they are dependent on the characteristics of the study area and the image data used.

\section{CONCLUSION}

This article shows how results obtained for biomass estimation are related to textures and spectral signatures of TM bands. Our findings indicate that textures are more effective in extracting aboveground biomass information for mature forests than for successional vegetation. As part of our research within the LBA program, we intend to test the procedures used in other western and eastern Amazonian sites. If the textures selected by this study are effective for mature forests basin-wide, we may be able to refine aboveground biomass estimations and, consequently, to improve the evaluations of potential carbon emissions that could be released to the atmosphere due to deforestation. Thus, our challenge is to develop complementary remote sensing methods that are effective to capture and monitor the variation of heterogeneous landscapes in the Amazon.

\section{ACKNOWLEDGMENTS}

The authors wish to thank the National Science Foundation (grants 95-21918 and 99-06826), the National Aeronautics and Space Administration (grant N005-334), and Brazil's CAPES (Program for the Advancement of Education) for their support, which provided funds for the research. We also thank collaborators in the LBA Program, EMBRAPA Satellite Monitoring, INPE, and the population of the study area in Brazil, who made this work possible. 


\section{LITERATURE CITED}

Augusteijn, M.F.; Clemens, L.E.; Shaw, K.A. 1995. Performance evaluation of texture measures for ground cover identification in satellite images by means of a neural network classifier. IEEE Transactions on Geoscience and Remote Sensing, 33: 616-625.

Batistella, M. 2001. Landscape change and land-use/land-cover dynamics in Rondônia, Brazilian Amazon, Ph.D. diss., Indiana University, Bloomington, Indiana, $399 \mathrm{p}$.

Batistella, M.; Robeson, S.; Moran, E. F. 2003. Settlement design, forest fragmentation, and landscape change in Rondônia, Amazônia. Photogrammetric Engineering and Remote Sensing, 69(7):805-812.

Bognola, I.A.; Soares, A.F. 1999. Solos das "glebas 01, 02, 03 e 06" do Município de Machadinho d'Oeste, RO. Pesquisa em Andamento, n.10. EMBRAPA Monitoramento por Satélite, Campinas, Brazil, $7 \mathrm{p}$.

Boyd, D.S.; Foody, G.M.; Curran, P.J. 1999. The relationship between the biomass of Cameroonian tropical forests and radiation reflected in middle infrared wavelengths (3.0-5.0um). International Journal of Remote Sensing, 20: 1017-1023.

Brown, I. F.; Martinelli, L.A.; Thomas, W.W.; Moreira, M.Z.; Cid Ferreira, C.A.; Victoria, R.A. 1995. Uncertainty in the biomass of Amazonian forests: an example from Rondônia, Brazil. Forest Ecology and Management, 75: 175-189.

Chavez, P.S. Jr. 1996. Image-based atmospheric corrections revisited and improved. Photogrammetric Engineering and Remote Sensing, 62: 1025-1036.

Chen, D.; Stow, D.A.; Gong, P. 2004. Examining the effect of spatial resolution and texture window size on classification accuracy: an urban environment case. International Journal of Remote Sensing, 25: 2177-2192.

Franklin, S.E.; Peddle, D.R. 1989. Spectral texture for improved class discrimination in complex terrain. International Journal of Remote Sensing, 10: 1437-1443.

Franklin, S.E.; Wulder, M.A.; Lavigne, M.B. 1996. Automated derivation of geographic window sizes for remote sensing digital image texture analysis. Computers and Geosciences, 22: 665-673.

Franklin, S.E.; Hall, R.J.; Moskal, L.M.; Maudie, A.J.; Lavigne, M.B. 2000. Incorporating texture into classification of forest species composition from airborne multispectral images. International Journal of Remote Sensing, 21: 61-79.

Haralick, R.M.; Shanmugam, K.; Dinstein, I. 1973. Textural features for image classification. IEEE Transactions on Systems, Man and Cybernetics, SMC-3: 610-620.

He, D.C.; Wang, L. 1990. Texture unit, textural spectrum and texture analysis. IEEE Transaction on Geoscience and Remote Sensing, 28: 509-512.

Honzák, M.; Lucas, R.M.; do Amaral, I.; Curran, P.J.; Foody, G.M.; Amaral, S. 1996. Estimation of the leaf area index and total biomass of tropical regenerating forests: a comparison of methodologies. In: Gash, J.H.C.; Nobre, C.A.; Roberts, J.M.;
Victoria, R.C. (Eds). Amazonian deforestation and climate. John Wiley \& Sons, Chichester, U.K., p.365-381.

Instituto Nacional de Pesquisas Espaciais (INPE). 2002. Monitoring of the Brazilian Amazon forest by satellite 20002001. INPE, Brazil, 23p.

Lu, D.; Mausel, P.; Brondizio, E.; Moran, E. 2002a. Above-ground biomass estimation of successional and mature forests using TM images in the Amazon basin. In: Richardson, D.; van Oosterom, P. (Eds.). Advances in Spatial Data Handling. Springer-Verlag, New York, p.183-196.

Lu, D.; Mausel, P.; Brondizio, E.; Moran, E. 2002b. Assessment of atmospheric correction methods for Landsat TM data applicable to Amazon basin LBA research. International Journal of Remote Sensing, 23: 2651-2671.

Lu, D.; Moran, E.; Batistella, M. 2003. Linear mixture model applied to Amazonian vegetation classification. Remote Sensing of Environment, 87: 456-469.

Lu, D.; Mausel, P.; Batistella, M.; Moran, E. 2004. Comparison of Land-Cover Classification Methods in the Brazilian Amazon Basin. Photogrammetric Engineering and Remote Sensing, 70: 723-731.

Marceau, D.J.; Howarth, P.J.; Dubois, J.M.; Gratton, D.J. 1990. Evaluation of the grey-level co-occurrence matrix method for land-cover classification using SPOT imagery. IEEE Transactions on Geoscience and Remote Sensing, 28: 513-519.

Moran, E.F. 1981. Developing the Amazon. Indiana University Press, Bloomington, Ind., 292p.

ndi Nyoungui, A.; Tonye, E.; Akono, A. 2002. Evaluation of speckle filtering and texture analysis methods for land cover classification from SAR images. International Journal of Remote Sensing, 23: 1895-1925.

Nelson, R.F.; Kimes, D.S.; Salas, W.A.; Routhier, M. 2000. Secondary forest age and tropical forest biomass estimation using Thematic Mapper imagery. Bioscience, 50: 419-431.

Podest, E.; Saatchi, S. 2002. Application of multiscale texture in classifying JERS-1 radar data over tropical vegetation. International Journal of Remote Sensing, 23: 1487-1506.

Riou, R.; Seyler, F. 1997. Textural analysis of tropical rain forest infrared satellite images. Photogrammetric Engineering and Remote Sensing, 63: 515-521.

Rondônia. 1998. Diagnóstico sócio-econômico do Estado de Rondônia e assistência técnica para formulação da segunda aproximação do zoneamento sócio-econômicoecológico - Climatologia, v.1. Governo de Rondônia/ PLANAFLORO, Porto Velho, Brasil. 401p.

Roy, P.S.; Ravan, S.A. 1996. Biomass estimation using satellite remote sensing data - an investigation on possible approaches for natural forest. Journal of Bioscience, 21: $535-561$.

Sader, S.A.; Waide, R.B.; Lawrence, W.T.; Joyce, A.T. 1989. Tropical forest biomass and successional age class relationships to a vegetation index derived from Landsat TM data. Remote Sensing of Environment, 28: 143-156. 
Spanner, M.A.; Pierce, L.L.; Peterson, D.L.; Running, S.W. 1990. Remote sensing of temperate coniferous leaf area index: the influence of canopy closure, understory vegetation, and background reflectance. International Journal of Remote Sensing, 11: 95-111.

Steininger, M.K. 2000. Satellite estimation of tropical secondary forest aboveground biomass data from Brazil and Bolivia. International Journal of Remote Sensing, 21: 1139-1157.
Unser, M. 1995. Texture classification and segmentation using wavelet frames. IEEE Transactions on Image Processing, 4: 1549-1560.

RECEBIDO EM 20/06/2003

ACEITO EM 25/10/2004 
